\title{
Persepsi Mahasiswa Pada Pelaksanaan CBT Ujian Akhir Semester Program Studi Tadris Biologi Fakultas Tarbiyah Dan Ilmu Keguruan IAIN Palangka Raya
}

\author{
Febry Ariyanti Syafitri ${ }^{*}$, Nurul Septiana \\ Program studi Tadris Biologi, Jurusan Pendidikan Matematika dan Ilmu Pengetahuan Alam, Fakultas \\ Tarbiyah dan Ilmu Keguruan, IAIN Palangkaraya, Palangkaraya, Kalimantan Tengah, Indonesia \\ Email : Febrysyafitri.06@gmail.com
}

\begin{abstract}
Abstrak
Penelitian ini bertujuan untuk mengetahui pendapat mahasiswa yang telah melaksanakan ujian akhir semester dengan menggunakan CBT (Computer Based Test). Metode dalam pengambilan data dengan menggunakan metode purposive sampling. Hasil yang didapatkan di lapangan menyajikan data mahasiswa yang sudah melakukan ujian dengan berbasis komputer. Data yang didapat kemudian dideskripsikan berdasarkan hasil angket yang dibagikan.Setelah dilakukan penelitian didapatkan simpulan bahwa penggunaan CBT (Computer Based Test) pada program studi tadris biologi dapat mempermudah pelaksanaan ujian akhir semester. Penggunaan CBT (Computer Based Test) pada ujian akhir semester program studi tadris biologi dapat terlaksana dengan baik dan maksimal yang dibuktikan dengan hasil presepsi mahasiswa mendapatkan respon setuju bahkan sangat setuju.
\end{abstract}

Kata Kunci: Persepsi, CBT, Biologi

\begin{abstract}
This study aims to determine the opinions of students who have carried out the final semester exams using CBT (Computer Based Test). The method of collecting data using purposive sampling method. The results obtained in the field present data on students who have taken computer-based exams. The data obtained were then described based on the results of questionnaires distributed. After conducting the research, it was concluded that the use of CBT (Computer Based Test) in the biology tadris study program can facilitate the implementation of the final semester exams. The use of CBT (Computer Based Test) in the final exam of the semester for the biology tadris study program can be carried out well and maximally as evidenced by the results of students' perceptions getting responses to agree and even strongly agree.
\end{abstract}

Keyword: Perception, CBT, Biology

\section{PENDAHULUAN}

Berdasarkan pasal 39 UU no 20 tahun 2003 tugas guru atau tenaga pendidik yaitu merencanakan pembelajaran, melaksanakan pembelajaran, menilai hasil pembelajaran, melakukan pembimbingan, melakukan pelatihan, melakukan penelitian, dan melakukan pengabdian masyarakat (UU RI Nomor 20 thn 2003). Dalam era globalisasi seperti sekarang ini tenaga pendidik dituntut lebih aktif dan kreatif dalam proses pembelajaran seperti halnya dalam pengambilan nilai atau dalam pelaksanaan ujian akhir. Dengan adanya teknologi seperti sekarang yang hampir semua bisa dilakukan dengan online atau melalui komputer, tenaga pengajar dituntut untuk bisa atau memahami cara kerja dari suatu teknologi yang berkaitan dengan pendidikan saat ini (Dwi, 2017).

Seperti yang kita ketahui saat ini penggunaan komputer dalam pembelajaran masih jarang dilakukan khususnya dalam pelaksanaan ulangan atau ujian akhir 
semester. Hanya beberapa tenaga pendidik yang melakukan ujian melalui daring atau online. Sisanya tenaga pendidik masih menggunakan cara yang lama atau seperti biasanya dengan membagikan kertas soal dan menjawab pada lembaran lainnya. Salah satu teknologi yang dapat digunakan dalam pemberian tugas dan pengambilan nilai yaitu dengan computer based test atau sering disebut dengan CBT (Alisandi dkk, 2018).

Berdasarkan hasil wawancara dengan mahasiswa penggunaan kertas pada lembar ujian lebih banyak memakan waktu dalam penegerjaannya khususnya untuk soal esay, seringkali mahasiswa kekurangan waktu dalam pengisian jawaban tersebut dan seringkali mahasiswa tidak sempat menjawab salah satu soal. Dalam pengisian soal dengan menggunkan kertas tidak jarang memerlukan lebih dari satu lembar kertas untuk menjawab soal. Jurusan MIPA IAIN Palangka Raya pada program studi tadris biologi masih banyak dosen yang melakukan evaluasi atau ujian akhir semester dengan menggunakan pengisian lembar jawaban, hanya beberapa dosen yang melakukan ujian dengan berbasis komputer atau CBT. Penulis tertarik mengetahui tanggapan mahasiswa mengenai pelaksanaan ujian dengan menggunakan CBT.

CBT (computer baed test) adalah salah satu teknologi dimasa sekarang yang bisa dimanfaat dalam dunia pendidikan atau yang lainnya. CBT juga memiliki kekurangan dan kelebihan. Dalam pelaksanaannya tidak semua orang merasa senang atau merasa tidak suka tetapi setiap orang memiliki pendapat masing-masing mengenai penggunaan teknologi yang ada seperti CBT atau tes berbasis komputer ini. Setiap orang mempunyai kecenderungan dalam melihat benda yang sama dengan cara yang berbedabeda. Perbedaan tersebut bisa dipengaruhi oleh banyak faktor, diantaranya adalah pengetahuan, pengalaman dan sudut pandangnya (Sugihartono \& Nufathiyah, 2007). Perbedaaan dalam melihat suatu objek tertentu biasanya disebut dengan pendapat atau persepsi. Menurut Slameto (2010) persepsi adalah proses yang menyangkut masuknya pesan atau informasi ke dalam otak manusia Melalui persepsi, manusia dapat terus menerus mengadakan hubungan dengan lingkungannya. Hubungan ini dilakukan lewat indera yaitu indera penglihat, pendengar, pencium, perasa, dan peraba.

\section{METODE}

Jenis penelitian ini termasuk dalam penelitian dengan pendekatan kualitatif, karena data diwujudkan dalam bentuk katakata berdasarkan hasil wawancara dilapangan dan juga angket guna mengetahui persepsi mahasiswa pada pelaksanaan CBT ujian akhir semester program studi tadris biologi (Sugiyono, 2013). Penelitian ini juga merupakan penelitian deskriptif yang dilakukan untuk mendeskripsikan atau menggambarkan objek penelitian dalam keadaan yang sebenarnya tanpa ada maksud membuat kesimpulan. Data yang telah terkumpul kemudian dideskripsikan dengan bantuan hasil observasi diawal penelitian, angket. 
Motede dalam penelitian ini dilakukan dengan pengumpulan data dengan cara menyebar angket terbuka dan tertutup dengan mengakse link yang telah dibagikan. Penelitian ini dilakukan pada mata kuliah yang melaksanakan ujian dengan menggunakan CBT. Dalam penelitian ini penulis melakukan penelitian dalam dua kelas yaitu kelas morfologi tumbuhan dan dasardasar pendidikan.

\section{HASIL DAN PEMBAHASAN}

Teknik pengumpulan data yang digunakan dalam penelitian ini menggunakan instrumen angket atau kuisioner, dengan cara membagikan angket kepada mahasiswa tadris biologi ke empat kelas. Angket persepsi mahasiswa terhadap pelaksanaan CBT terdapat dua jenis yaitu angket tertutup dan angket terbuka. Angket tertutup dihitung dengan cara banyaknya jumlah skor dan dibagi dengan seluruh butir pertanyaan. Hasil perhitungan dapat digolongkan sangat setuju jika mencapai $75 \%$ dan sangat buruk jika hasil perhitungan dibawah $25 \%$.

Jumlah pernyataan pada angket tertutup sebanyak 25 butir pertanyaan, dan dari setiap indikator terdapat beberapa butir pertanyaan yang terdiri dari pertanyaan positif dan negatif. Pengelompokan gejala yang diamati dari masing-masing penilaian responden terhadap indikatorindikator dalam angket persepsi mahasiswa tadris biologi pada pelaksanaan CBT dibedakan menjadi empat kategori yaitu sangat setuju, setuju, kurang setuju, dan tidak setuju.
Berdasarkan hasil keseluruhan jawaban mahasiswa pada angket tertutup yang berjumlah 25 butir pertanyaan menunjukkan bahwa persepsi mahasiswa pada pelaksanaan CBT dengan 38 responden dengan hasil persepsi sangat setuju (SS) sebanyak $15,25 \%$ mempunyai persepsi setuju (S) sebanyak $47.9 \%$ mempunyai persepsi kurang setuju (KS) sebanyak 29,4\% dan yang mempunyai persepsi yang tidak setuju (TS) sebanyak $7 \%$ positif, adapun diagaram batang hasil penelitian dapat dilihat sebagai berikut:

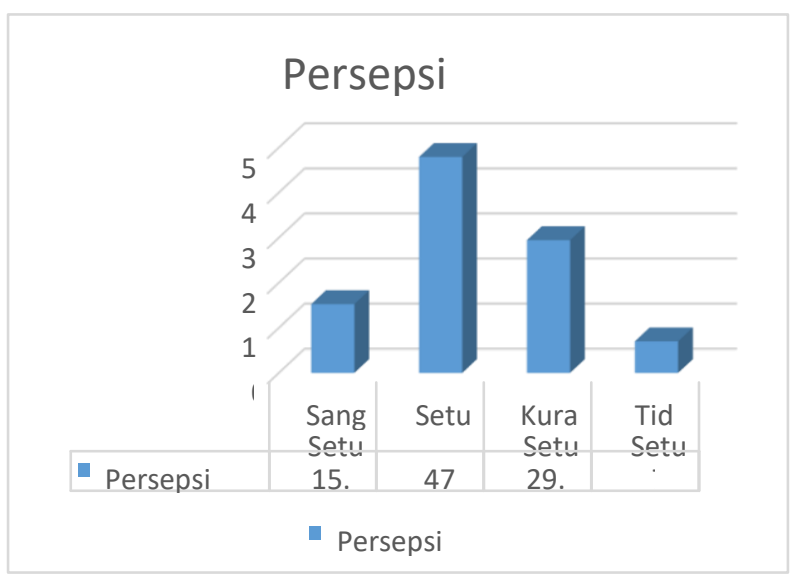

Gambar 1 Perbandingan Persepsi mahasiswa pada pelaksanaan CBT ujian akhir semester program studi tadris biologi $2019 / 2020$

Dengan demikian dapat dikatakan bahwa persepsi mahasiswa pada pelaksanaan CBT ujian akhir semester program studi tadris biologi 2019/2020 dianalisis dari hasil perhitungan butir angket tertutup skor persepsi $=47,3 \%$ masuk ke dalam kategori setuju dan persepsi $=15,25 \%$ masuk ke dalam kategori sangat setuju. Dengan artian bahwa setengah 
dari responden menyukai ujian dengan menggunakan CBT.

Angket terbuka dalam instrumen penelitian ini terdiri dari 10 butir pertanyaan mengenai penggunaan CBT (computer based test) dalam ujian akhir semester. Angket terbuka ini lebih mengarahkan kepada pendapat mahasiswa tentang kekurangan dan kelebihan atau perbandingan penggunaan CBT (computer based test) dengan ujian dengan pengisian lembar jawaban paper based test. Serta ada butir soal yang menanyakan pengelaman mahasiswa melakukan ujian dengan berbasis IT sebelum di IAIN Palangka Raya.

Berdasarkan data keseluruhan angket tertutup mayoritas mahasiswa mempunyai respon positif dengan penggunaan CBT pada ujian akhir semester. Mahasiwa yang mempunyai respon positif terhadap pelaksanaan ujian dengan berbasis IT ini sebanyak 24 mahasiswa dalam presentase $63,15 \%$.

Alasan mahasiswa memberikan respon positif ini diungkapkan mahasiswa pada angket terbuka yang menyebutkan bahwa ujian dengan menggunakan CBT (computer based test) lebih mudah dalam hal pengisian. Alasan lain mahasiswa memberi respon positif yaitu efesien dalam waktu pengerjaan soal dan hasil jawaban dapat diperiksa otomatis serta objektif serta pelaksanaan ujian yang dapat dilakukan tanpa mengharuskan terjadinya tatap muka atau pengawas dan peserta berada pada ruangan yang sama. Penggunaan internet atau pembelajaran virtual ini sangat penting pada saat kondisi sekarang yang teknologi sudah berkembang pesat bukan hanya pada bidang ekonomi, politik pendidikan pun juga harus bisa menerapkan dan mengimbangi pembelajaran dengan zaman yang sudah serba modern seperti sekarang ini (Lestanto, 2018).

Alasan responden memberikan jawaban setuju dalam efektifitas waktu tergantung dari soal yang diberikan jika soal dirasa sulit maka waktu yang telah disediakan dirasa kurang, jika peserta ujian merasa soal yang disediakan cukup mudah waktu dirasa cukup bahkan kadang kelebihan. Faktor lain yang menyebabkan mereka mengatakan waktu pengerjaan yang efesien dikarenakan peneulisan jawaban yang diketik tanpa harus menulis, dan jika peserta salah dalam penulisan peserta dapat langsung menghapus pada layar tanpa harus menunggu keringnya penghapus tulisan yang biasanya digunakan pada kertas atau mengganti kertas jika lembar jawaban rusak atau sudah tidak layak digunakan.

\section{SIMPULAN}

Berdasarkan data hasil penelitian pada mahasiswa program studi tadris biologi IAIN Palangka Raya dapat disimpulkan bahwa mahasiswa mayoritas mempunyai persepsi sangat positif terhadap pelaksanaan ujian dengan menggunakan CBT. Alasan mahasiswa memberikan respon positif dalam penggunaan CBT karena penggunaan yang mudah, pengisian jawaban lebih cepat, dapat menghemat penggunaan kertas, waktu lebih efisien, pengkoreksian jawaban dilakukan 
dengan otomatis serta objektif. Jadi secara keseluruhan persepsi mahasiswa program studi tadris biologi mengenai pelaksanaan ujian dengan menggunakan CBT dalam kategori positif dengan artian lain bahwa ujian dengan berbasis IT ini dapat diterima dan disukai mayoritas mahasiswa.

\section{DAFTAR PUSTAKA}

Arisandi D, Rachmawati D. Aulia I. 2018. Pengembangan computer-based test sebagai strategi peningkatan efisiensi evaluasi kegiatan belajar mengajar. Juripol. 1(2): 3-4.

Dwi FP. 2017. Computer based test (CBT) pada sekolah tinggi tarakantina jakarta menggunakan metode computerized fixed-form test (CFT). Jurnal Ilmiah teknologi Informasi. 4(1): 6.

Lestanto P. 2018. Persepsi Mahasiswa dalam Pembelajaran Online Pengembanagan Teori dari Penelitian Berjudul Mpersepsi Mahasiswa Terhadap Materi Ajar Pada Pembelajaran Online. Jurnal Bahasa dan Sastra. 10(2): 105-110.

Slameto. 2010. Belajar dan faktor-faktor yang mempengaruhinya. Jakarta: Rineka Cipta.

Sugiyono. 2013. Metode Penelitian Kuantitatif, Kualitatif dan $R \& D$. Bandung: Alfabeta.

Sugihartono, Nurfathiyah. 2007. Psikologi Pendidikan. Yogyakarta : UNY. 